\title{
A case for multimodal training of electronic databases at a higher education institution
}

\author{
E.M. Stoffberg' \\ Library and Information Services, Tshwane University of Technology Private Bag X680, \\ Pretoria 0002, South Africa \\ esterhuizenem@tut.ac.za
}

and

A.S. Blignaut ${ }^{2}$

Faculty of Education, North West University Potchefstroom, South Africa

Seugnet.Blignaut@nwu.ac.za

\begin{abstract}
Received: $12^{\text {th }}$ December 2006
Accepted: $29^{\text {th }}$ October 2007

This paper analyses and evaluates the current institutional Information Literacy Training Programme (ILTP) at the Tshwane University of Technology. The Library and Information Services re-examines its ILTPs from previously merged Technikons in terms of the background and conditions as well as the design and approval of a new programme. This baseline evaluation examines the development of a training programme for scholars using electronic databases in the contact on-campus delivery mode and to the proposed multimodal training approach. We recommend the content, format, assessment approaches and delivery mode for the ILTP.
\end{abstract}

Keywords: Information literacy; electronic databases; academic libraries; online learning; multimodal learning

\section{Introduction}

Databases in the information world have changed from merely card systems to sophisticated electronic research tools, demanding very specific user skills. Students and staff members are per se not trained to use the new media. Former Information literacy training programmes (ITLP) designed to transfer literacy skills are generally presented only oncampus and are not web-enabled. With the merger of three former technikons (Technikon Pretoria, Technikon Northern Gauteng, Technikon North-West), Tshwane University of Technology (TUT) faces a new dispensation that demands new approaches to ensure the accommodation of all stakeholders. A transparent design and development process should include both the technology-enabled generation as well as previously disadvantaged student communities.

\section{Background}

At TUT we realise the importance of Information Literacy to support students in their learning, enhance their careers and ultimately promote lifelong learning (Zinn, 2000, De Jager and Sayed, 1998). Consequently, we designed and developed an ILTP according to the Australian and New Zealand Information Literacy Framework standards for the dissemination of the knowledge and skills of dealing with online electronic databases (Bundy, 2004).

We faced a number of challenges to successfully introduce the new programme as information literacy training is a relatively new library function. Unexpected new factors such as large classes, insufficient library staff to meet the training demand and inadequate training facilities such as appropriately equipped lecture and computer training rooms confronted us. The current ILTP is a voluntary training initiative and the Institution makes no provision in its timetables for students to attend information literacy training sessions. Moreover, faculty frequently requests library staff to address specific domain-related objectives during training sessions. Librarians are generally not prepared to facilitate large student groups. The traditional contact programme almost completely excludes off-campus students unless librarians visit the remote learning sites. The vast increase of distant learners at TUT compels librarians to support and to provide for such students (Ojedokun, 2000). Therefore, ILTP doesn't reach the students targeted in TUT's Information Literacy policy (TUT Library and Information Services, 2005a).

Inadequate allocation of financial and human resources leads to severe constraints on the effective development and implementation of a profound ILTP. A team consisting of a single training librarian cannot make full use of the advances in

I. Ms Elsa Stoffberg is a Training Librarian, Library and Information Services, Tshwane University of Technology Pretoria Campus, South Africa.

2. Seugnet Blignaut, PhD, is Professor of Continuing Education, Faculty of Educational Studies, North-West University, Potchefstroom Campus, South Africa. 
ICT for education in terms of design, development, implementation, evaluation and maintenance of a programme of this scale. The demand calls not only for the support of librarians, and for providing training facilities such as computer and training rooms, but also for additional educational technology aids such as data projectors, DVD players, headphones and interactive classroom-management systems. These created huge and unexpected demands on the library budget.

\section{Initiating the information literacy training programme}

In February 2005 the LIS executive committee (EXCO) formulated its strategic and executive plans for 2005 and beyond, including the development and implementation of an ILTP (TUT Library and Information Services, 2005b). The LIS EXCO mandated the Information Literacy Training Committee to design, develop, and implement an ILTP at TUT to integrate access of information resources for the development of students' academic, extra-curricular and personal and career development activities. At the meeting in August 2005, the Information Literacy workgroup proposed a draft policy on Information Literacy training that mandated targeting all TUT students and academics, meeting the institutional requirements for academic programmes, and aligning the programme to the TUT skills and development policies (TUT Library and Information Services, 2005c).

The LIS became the first non-academic department represented in the Partners@Work initiative of the Directorate of Telematic Education (TE) at TUT. This programme provides a year-long intensive training and development in curriculum design, pedagogy, online student-support, communication and the use of technology at higher educational institutions. This initiative aligns with the Virtual Learning Environment (VLE) training programme of the Waterford Institute of Technology Libraries, Waterford, Ireland (Quinlan and Hegarty, 2006). Ms V. Agyei, Executive Director of LIS, appointed the training librarian to the project for the period of July 2005-June 2006 (TUT Library and Information Services, 2005a). The training librarian had to explore, investigate and augment the ILTP according to the specifications of the South African Qualifications Authority's (SAQA) She also redesigned the contextual aspects of the programme, selected and assigned appropriate educational technologies to enhance teaching and learning, and made the programme accessible within the constraints of budgetary and human resources.

\section{Information literacy training programmes}

Nationally and internationally higher education institutions list the required information literacy skills to successfully conduct independent study. These include the recognition of required information, the ability to retrieve the information from library catalogues, electronic databases or other collections, and the skill to use the information delivered to users in different formats (Tucker and Palmer, 2003). Information-literate students should be able to assess the value of information (peer-reviewed versus popular information) and effectively use it within ethical and legal boundaries of plagiarism and copyright. Such competencies enable developing students to operate as citizens of the knowledge society (Maybee, 2006).

We grouped the various information literacy content and skills as modules for the new ILTP (Table I). Module five (Electronic Databases) is a crucial component for all students and academics as it includes the independent retrieval, evaluation, and application of recent peer-reviewed electronic information.

Table I Modules of the Information Literacy Training Programme at TUT

\begin{tabular}{ll}
\hline Module I & Introduce the library and its services. \\
Module 2 & Locate information in the library by using the library homepage and in-house databases. \\
Module 3 & Use relevant formats of printed and multimedia. \\
Module 4 & Access, retrieve, evaluate, and apply scholarly information published on the Internet. \\
Module 5 & Identify and use electronic databases on the Electronic Resources Portal. \\
Module 6 & Use the Harvard style of referencing in research reports. \\
\hline
\end{tabular}

During the first four months of 2006 we received requests for Module Five training from many academic departments. Due to insufficient resources, it was not possible to accommodate all requests. The high demand for training on electronic databases, as well as the imperative to change the delivery mode, Module Five (Table I) became the first module developed and delivered in the new format.

\section{Baseline evaluation of the existing information literacy programme}

We performed a baseline evaluation of the existing module as a first step in the design, development, and implementation to determine the instruction mode best suited for Module Five (Cognitive Aptitude Assessment, 2004). This included listing learning outcomes, presentation methods, media, facilities, learning content and presentation modes of the six sub- 
units of module five. We standardised, designed and customised the module content according to national and international standards. Six specific outcomes made up the module (Table2).

Table 2 Baseline evaluation of the existing training Module Five

\begin{tabular}{|c|c|c|c|c|}
\hline Time: 180 minutes & Identify and use electronic databases on the El & rces Portal (ER & & \\
\hline Units & Specific outcomes & Methods & Media & Facilities \\
\hline $\begin{array}{l}5.1 \\
\text { Characteristics and } \\
\text { terminologies of } \\
\text { electronic databases }\end{array}$ & $\begin{array}{l}\text { Familiarise students with } \\
\text { - database characteristics } \\
\text { - terminologies } \\
\text { - types } \\
\text { - nature of electronic information }\end{array}$ & \multirow{6}{*}{ 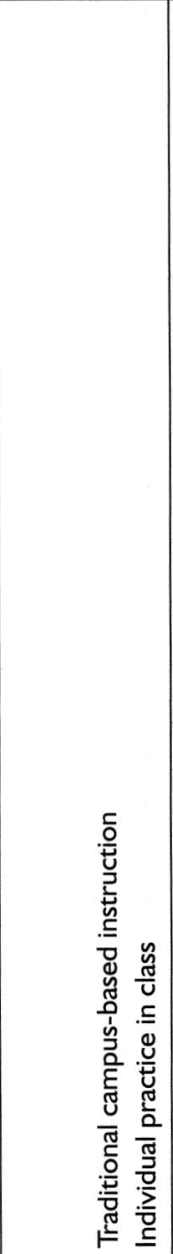 } & \multirow{6}{*}{ 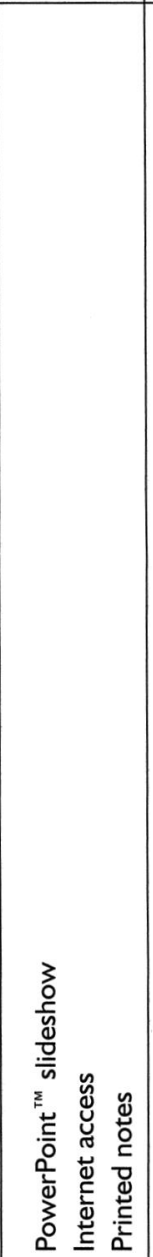 } & \multirow{6}{*}{ 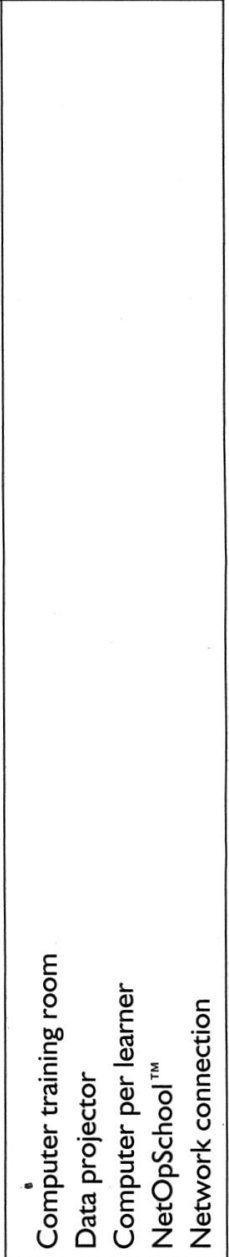 } \\
\hline $\begin{array}{l}5.2 \\
\text { Access to the ERP }\end{array}$ & $\begin{array}{l}\text { Introduce students to } \\
\text { - access the LIS homepage } \\
\text { - logon to the ERP with own student number } \\
\text { - navigate and retrieve electronic resources } \\
\text { - logon to a database } \\
\text { - use URL and ERP logon information }\end{array}$ & & & \\
\hline $\begin{array}{l}5.3 \\
\text { Selection of databases }\end{array}$ & $\begin{array}{l}\text { Introduce students to } \\
\text { - available databases } \\
\text { - database coverage } \\
\text { - specific databases }\end{array}$ & & & \\
\hline $\begin{array}{l}5.4 \\
\text { Search techniques }\end{array}$ & $\begin{array}{l}\text { Allow students to } \\
\text { - identify a specific topic } \\
\text { - analyse a topic } \\
\text { - use Boolean operators } \\
\text { - use truncation } \\
\text { - optimise search results }\end{array}$ & & & \\
\hline $\begin{array}{l}5.5 \\
\text { Evaluation criteria }\end{array}$ & $\begin{array}{l}\text { Allow students to } \\
\text { - search popular and scholarly information } \\
\text { - evaluate Internet-based information } \\
\text { - evaluate electronic databases information }\end{array}$ & & & \\
\hline $\begin{array}{l}5.6 \\
\text { Practical experience }\end{array}$ & $\begin{array}{l}\text { Demonstrate successful } \\
\text { - access to ERP information } \\
\text { - selection of appropriate databases } \\
\text { - planning of search strategies } \\
\text { - retrieval and refining of search results } \\
\text { - marking and exporting of articles }\end{array}$ & & & \\
\hline
\end{tabular}

At the Pretoria learning site, Module Five training normally comprises a 180 minute contact session with 20-30 participants in a computer training room with direct access to the electronic databases. During this campus-based training we use animated demonstrations or direct access of electronic databases to enhance the learning. NetOpSchool ${ }^{\mathrm{Tm}}$, a network program, creates a trainer-controlled computer classroom that enables the trainer to access participants' computers from a console and attend to their learning problems without scurrying from student to student. The limited number of students and the controlled environment ensure a smooth course delivery and ease the participants through the basic procedures to advanced and more complex searches. The time allocated is normally sufficient to complete the scheduled learning tasks.

\section{Advantages of the existing programme}

During a contact session we interact with a spectrum of knowledge and information on electronic databases relating to terminology, retrieval, and the evaluation of information. Although it requires more preparation, we customise examples for different disciplines, subject areas and user groups. Trainees access the electronic databases via computer terminals to practise and apply their newly attained information-literacy skills under the guidance of the training librarian. Training sessions are scheduled according to the time table of the user group.

\section{Challenges of the existing programme}

The low number of trainees per session, dependent on the size and availability of the computer training room, results in frequent repetitions to accommodate large classes. The many repetitions demand much time from the training librarian. Students rely upon their lecturers to initiate and schedule training sessions for them. Moreover, these sessions also SA JnI Libs \& Info Sci 2008, 74(I) 
require the presence of information technology (IT) support staff to ensure technical efficacy. Only on-campus students can currently be accommodated, leaving little chance for off-campus or part-time students to attend training sessions. As information literacy training is not compulsory, many students never attain these skills.

We soon realised that the students needed basic computer literacy skills for the training programme. Students with insufficient skill are referred to a campus computer literacy training programme before commencing the ILTP. However, Don Tapscott (1998) refers to the first generation of students that grew up with electronic technology as the "Net Generation". Lippencott (2005) points out that the Net generation may be technology-savvy but lacks basic academic and research skills. A new ILTP should provide for TUT's diversity in student competencies.

Currently, course notes are distributed during training sessions, but they should form an integral part of the new ILTP. Course notes should also be available in a variety of formats to accommodate all users.

Many students prefer to seek information via the Internet. Lippencott (2005) maintains that only $28 \%$ of Colorado State University students use databases, while $58 \%$ use Google ${ }^{\mathrm{TM}}$ and other search engines for information searches. The crucial issue, therefore, is that web-enabled students' first search in Google, and thereafter seek the traditional library web pages and library catalogues. A new ILTP should recognise this tendency.

\section{Current contact training mode versus multimodal training approaches}

Table 3 Comparison of contact tuition, online delivery and multimodal training approaches

\begin{tabular}{|c|c|c|c|}
\hline Aspect & Contact mode & Online delivery & Multimodal training \\
\hline Content & $\begin{array}{l}\text { - Stable content } \\
\text { - Uniform training } \\
\text { - Fixed order of content }\end{array}$ & $\begin{array}{l}\text { - Flexible content } \\
\text { - Flexible order of content } \\
\text { - Additional links } \\
\text { - Remote access } \\
\text { - Self-paced exercises }\end{array}$ & $\begin{array}{l}\text { - Stable content } \\
\text { - Flexible order of content } \\
\text { - Linked to media } \\
\text { - Combination of notes, CD-ROMs } \\
\text { and online formats }\end{array}$ \\
\hline $\begin{array}{l}\text { Learning } \\
\text { outcomes }\end{array}$ & $\begin{array}{l}\text { - Achievable learning outcomes } \\
\text { - Locus of control with trainer }\end{array}$ & $\begin{array}{l}\text { - Achievable outcomes } \\
\text { - Locus of control with student }\end{array}$ & $\begin{array}{l}\text { - Achievable outcomes } \\
\text { - Locus of control with student }\end{array}$ \\
\hline Duration & - 180 minutes & $\begin{array}{l}\text { - Self-determinate } \\
\text { - Self-paced } \\
\text { - Reliant on system speed }\end{array}$ & $\begin{array}{l}\text { - Self-determinate } \\
\text { - Reliant on system speed }\end{array}$ \\
\hline Access & - On campus & $\begin{array}{l}\text { - On campus } \\
\text { - Off campus }\end{array}$ & $\begin{array}{l}\text { - On campus } \\
\text { - Off campus }\end{array}$ \\
\hline $\begin{array}{l}\text { Computer } \\
\text { literacy }\end{array}$ & $\begin{array}{l}\text { - Web browsers } \\
\text { - e-Mail } \\
\text { - MS Word }{ }^{\mathrm{TM}} \\
\text { - PDFs }\end{array}$ & $\begin{array}{l}\text { - Web browsers } \\
\text { - e-Mail } \\
\text { - MS Word }{ }^{\mathrm{TM}} \\
\text { - PDFs }\end{array}$ & $\begin{array}{l}\text { - Web browsers } \\
\text { - e-Mail } \\
\text { - MS Word }{ }^{\mathrm{rm}} \\
\text { - PDFs } \\
\text { - Additional media }\end{array}$ \\
\hline $\begin{array}{l}\text { Training } \\
\text { schedule }\end{array}$ & $\begin{array}{l}\text { - Scheduled classes } \\
\text { - Customized sessions } \\
\text { - Insufficient opportunities }\end{array}$ & $\begin{array}{l}\text { - Any time } \\
\text { - Any where } \\
\text { - Indefinite repeats }\end{array}$ & $\begin{array}{l}\text { - Any time } \\
\text { - Any where } \\
\text { - Indefinite repeats }\end{array}$ \\
\hline Availability & $\begin{array}{l}\text { - On campus } \\
\text { - Scheduled hours } \\
\text { - Librarian's office hours }\end{array}$ & $\begin{array}{l}\text { - Any time } \\
\text { - LMS dependant }\end{array}$ & $\begin{array}{l}\text { - Any time } \\
\text { - LMS dependant } \\
\text { - Available as separate media }\end{array}$ \\
\hline Facilities & $\begin{array}{l}\text { - On-campus computer training facility } \\
\text { - Off-campus computer training facilities } \\
\text { at other learning sites }\end{array}$ & $\begin{array}{l}\text { - Any-where } \\
\text { - Off campus computers } \\
\text { - Internet access }\end{array}$ & $\begin{array}{l}\text { - Any where } \\
\text { - Off-campus computers } \\
\text { - Internet access }\end{array}$ \\
\hline
\end{tabular}

Online instruction should take its rightful place next to on-campus training to serve the broad and divers community of learners (Gutierrez and Wang, 200I). Librarians spend much time and effort on campus students, while the LIS policy stipulates that the broader TUT cliental should be served via the electronic media. A multimodal technology-based approach to training can address many of the above-mentioned challenges. Technology ensures students' access to 
training material from remote sites in their own time and at their own pace (Tricarico et al., 200I). Flexible learning becomes possible -- catering to all students' requirements by removing the barriers of time, space and location (Thórsteinsdóttir, 200I, Scott and Alexander, 2000). A real student-centred approach then becomes viable. E-learning provides the opportunity to use powerful multimedia for learning, resulting in cost benefits for the institution. Also, online and multimodal approaches demand the use of a wider range of resources than before. Table 3 provides a summary of the different training approaches.

Online tutorials and multimedia should supplement, not replace, the human intervention (Gutierrez and Wang, 200I). UNISA augments written assignments and examinations through a student-tracking system that includes study guides and various self-paced activities (Machet and Behrens, 2000). UNISA realises that study material should also be available in printable format, be presented in a short period of time include practical contact sessions, and contain generic explanations and examples. They accomplished all this with a reduced staff (Machet, 2005). At TUT, we encountered many of the same challenges when redesigning a new ILTP.

\section{Student statistics and training numbers}

TUT's registration and training statistics indicated that the LIS does not attain its goal of serving the intended student population. In this paper, we list statistics from the Pretoria learning site to report the current situation and make future projections (Table 4).

Table 4 Pretoria learning site student and Module Five training statistics

\begin{tabular}{|l|l|l|l|}
\hline Training & 2004 (Jan-Aug) & 2005 (Jan-Aug) & 2006 (Jan-March) \\
\hline$I^{\text {st }}$ year students & 8093 & $745 I$ & 6252 \\
$\begin{array}{l}\text { Number of trainees: } \\
\text { - Practical (I80 minutes) }\end{array}$ & 107 & 139 & 0 \\
- Lecture (60 minutes) & 57 & 67 & 0 \\
\% receiving training & $2,03 \%$ & $2,8 \%$ & 0 \\
\hline $2^{\text {nd }}$ and $3^{\text {rd }}$ year students & 26357 & 26533 & 23035 \\
Number of trainees & 23 & 0 & 0 \\
$\%$ receiving training & $0,08 \%$ & 0 & 0 \\
\hline $\begin{array}{l}\text { Postgraduate Students } \\
\text { Number of trainees: }\end{array}$ & 1230 & 1304 & 987 \\
- Practical & 73 & 52 & 41 \\
- Lecture & 272 & 173 & 150 \\
$\%$ receiving training & $28 \%$ & $17,3 \%$ & $19,3 \%$ \\
\hline
\end{tabular}

Table 4 indicates that in 2004 , of the $28 \%$ post-graduate students only $5.3 \%$ received practical training, while $24.7 \%$ attended a one hour lecture. In 2005 these numbers declined to $4 \%$ for the practical training and $13.3 \%$ for the lecture. In $2006,4.1 \%$ received practical training and $15.2 \%$ attended a lecture. However, from our experience, the students that only attended the lecture were more likely to return for information librarian support. It is also clear that the percentage of students who attained Module Five training remains disappointingly low. It is therefore a priority to re-design the programme and provide equal opportunities to off-campus and part-time students while maintaining skills proficiency. However, only the Pretoria learning site has a training librarian and the appointment of more training librarians is essential.

\section{Proposed framework for an ILTP}

We compiled a proposed framework to address issues of quality training, while increasing trainee numbers. We adapted and expanded the ILTP modules to optimise students' learning experiences with as many Critical Cross Field Outcomes as possible (South African Qualifications Authority, 2000). This included a unique combination of media, online activities and assessment strategies to match learning outcomes with contemporary delivery approaches (Scott and Alexander, 2000, Maybee, 2006, Lippencott, 2005, Quinlan and Hegarty, 2006).

It was difficult to re-engineer an on-campus programme for a distributed delivery mode (Heller-Ross, 1999). Online tutorials should be designed with for a specific target audience, contain suitable text, include interactive aspects, contain effective graphics, provide efficient online help, present a fun-filled environment, and display screen dumps to guide the student (Tricarico et al., 200I).

SA JnI Libs \& Info Sci 2008, 74(I) 
We approached the design and development of the ILTP in phases: commencing with re-evaluating the existing programme through a baseline evaluation, planning the next steps, and constructing a proposed format for the framework. We also took into account the particular requirements of the TUT students, the low budget and staffing constraints, availability of infrastructure, and the existing skills and competencies of the training librarian. In many respects, the training librarian benefited from the Partners@Work programme, and her new skills widely contributed to the new framework. Her newly attained skills included the exposure to a variety of media, curriculum-development strategies and web-based teaching skills.

As the ILTP training is voluntary, the training librarian aimed not to create a formal academic approach but a fun, enjoyable, and memorable online experience. The contemporary graphic user interface (GUI) appeals to students through a colourful, light-hearted and playful tone; the playful content characters; and a motivating storyline. Figure I indicates how the character associated with Module Five, Jonathan Spooner, engages with a virtual librarian through dialogue.

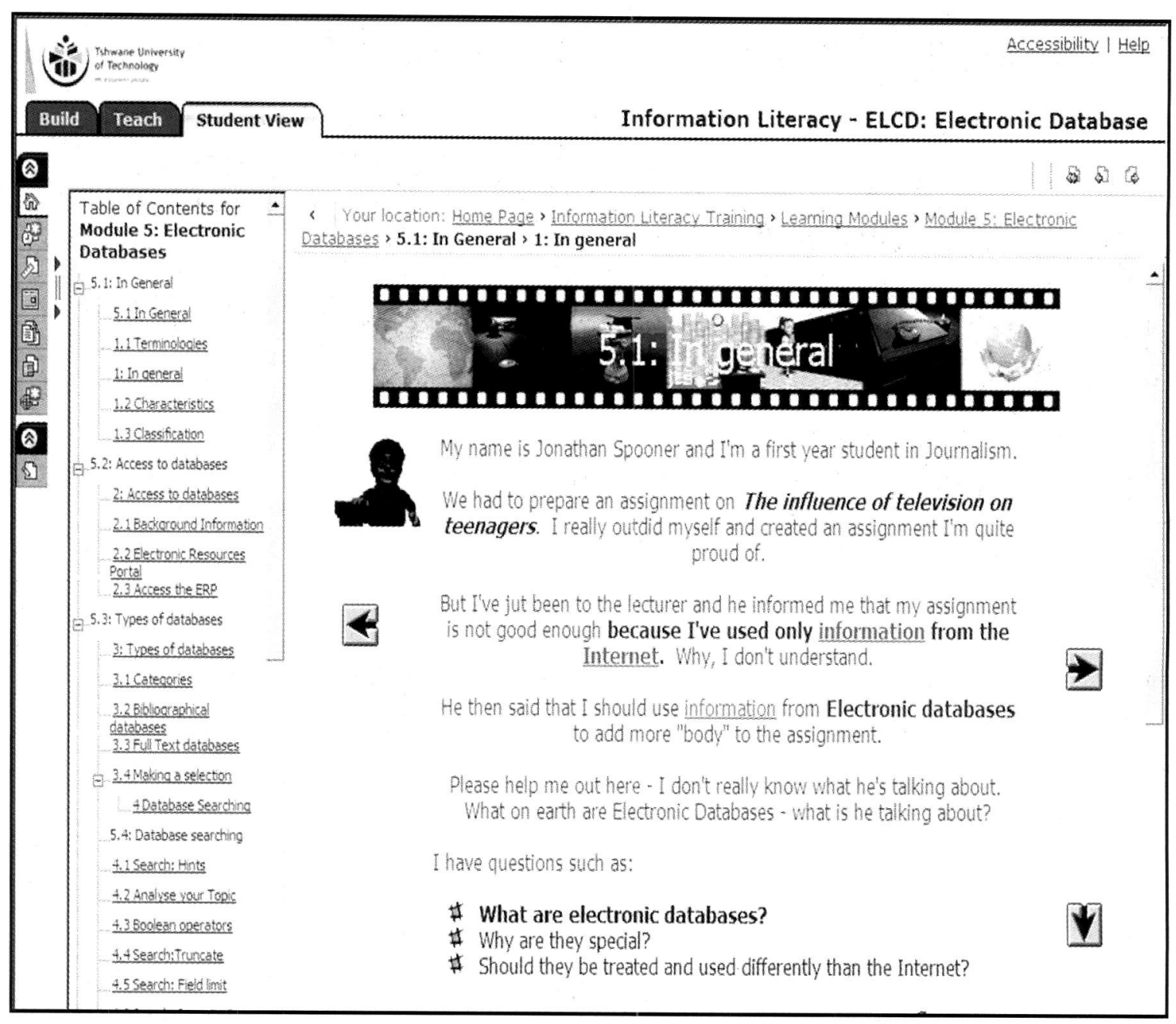

Figure 1 Graphic user interface of the ILTP

Module Five consists of six learning units linked via a central menu system (Figure I). Students freely navigate among the pages and they are not restricted by time to attain the information. To enhance the learning experience, we added the following: a glossary of more than 350 terms; an online guide consisting of an introduction, contact information, site structure; a list of modules in the ILTP outcomes; and assessment criteria of the ILTP. We also added supplementary links to additional information on information search techniques, database terminology, and examples relevant to students' assignments. The frequently-asked-question section refers inter alia to questions such as, "Which databases can I use to obtain reference to SA articles?", "I need to know the latest international research on my topic", or "I need full text information on my topic."

Student activities included online quizzes to reinforce contextual aspects (created with an HTML template), electronic tests at the end of units (created with Respondus ${ }^{T M}$ ), Internet crossword puzzles (created with EclipseCrossword ${ }^{T M}$ ), challenges and solutions, online flash cards, games and fill-in-the-blanks exercises (created with StudyMate ${ }^{\mathrm{TM}}$ ). At the end 
of each sub-unit, media on an interactive DVD explains particular issues further. Web-enabled slideshows (created in MS PowerPoint $^{\mathrm{TM}}$ and converted with Impatica ${ }^{\mathrm{TM}}$ ), video clips (captured with Camtasia ${ }^{\mathrm{TM}}$ ), and text documents (in PDF) aim to simulate the use of databases.

The outcomes and assessment criteria (in compliance with the SAQA (South African Qualifications Authority, 2000) and institutional standards for academic programmes) forms part of the informal assessment of the programme and a no credit test follows the programme. However, we aim to determine if students acquired the information literacy skills. The end-of-programme summative assessment verifies that students are became information literacy users. They are required to identify the database to retrieve specific information, create search statements, access specific databases, execute and refine searches, select and mark appropriate articles, and export them to an email box.

However, a number of aspects remain unresolved and will be addressed during the next phase of programme development. These include: group-work assignments, interactive e-mail communication between programme participants and library staff, a help-desk for additional support to users, the marketing of the ILTP amongst its users, as well as inclusion of the ILTP into the TUT web portal. All of these require wide-ranging competencies from a team of developers -- including role players such as training librarians, curriculum developers, graphical artists, web developers and course facilitators.

\section{Peer review of the proposed programme}

To ensure that the new ILTP was inclusive, efficient and visually appealing, we conducted three peer reviews of the ILTP with the library staff from the Pretoria, Soshanguve and Ga-Rankuwa learning sites. These took place on 4, 5 and 17 May 2006 when nineteen staff members evaluated the appearance of the programme, the animations, navigational aspects, student guides and interactive activities of the online Module Five. The evaluations clearly indicated a positive review of the proposed format, and they allocated a full score to the appearance, animation and guides. Navigational aspects received a 94\% approval (Figure 2). The evaluation of student activities such as electronic quizzes, tests, games and selfactivities also received a high appraisal (Figure 3 ).

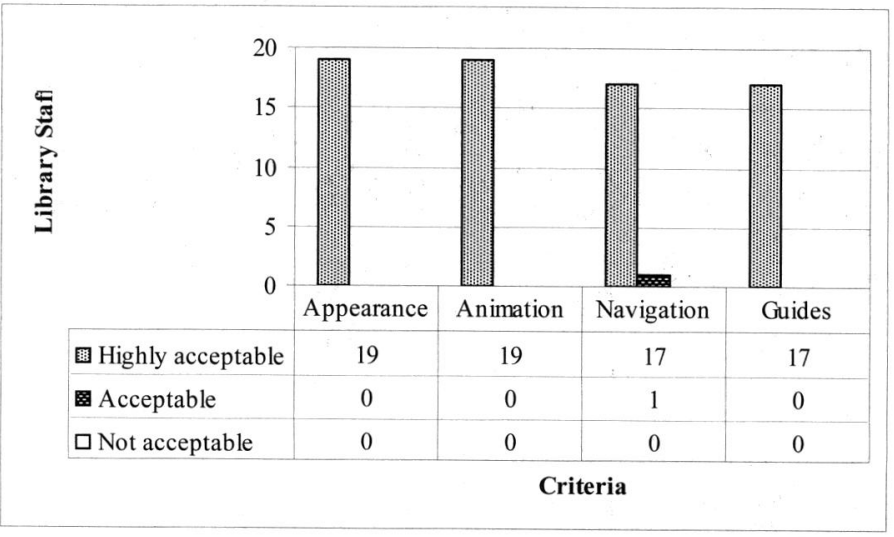

Figure 2 Peer review of the graphical user interface of the proposed ILTP

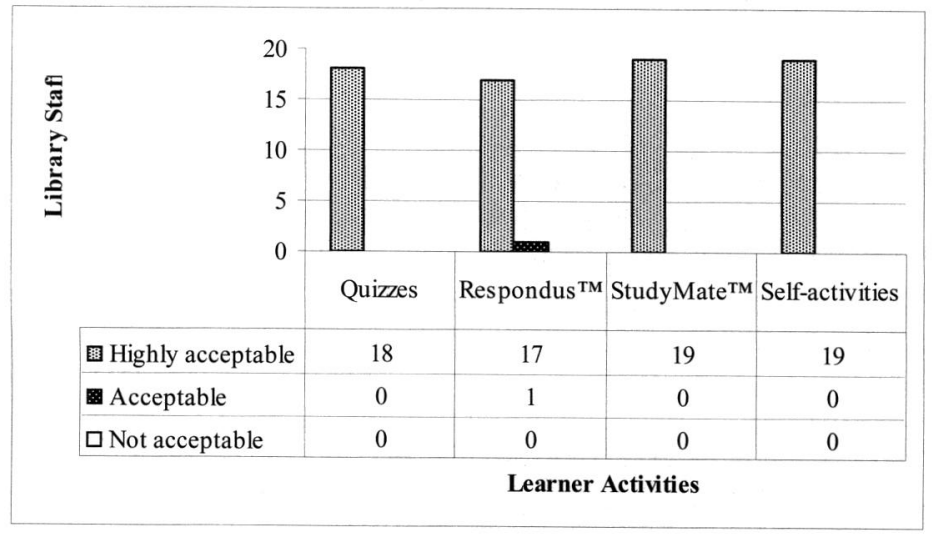

Figure 3 Peer evaluation of learner activities in the proposed ILTP 
All student activities, with the exception of the electronic tests, received full marks from the library staff. In their comments they observed, "The students will enjoy all the different levels of activities"; "Excellent work. I do like the format", "Never seen something like this"; "the programme is fantastic", and "It is user friendly". The peer review mandated the training librarian to proceed with the design and development of the remaining sections of the ILTP according to the proposed format.

\section{Conclusions}

The merger of technikons necessitated the LIS to re-visiting their existing Information Literacy Training Programme to ensure that the new student community housed at the nine learning sites is best served by a generic information literacy programme. The baseline evaluation of the programme, with special reference to Module Five (Electronic Databases), clearly indicated the best practices and areas of improvement. The continued development of the proposed ILTP entails a continued close-cooperation with the Directorate of Telematic Education of the TUT, IT services, Directorate Curriculum Development and Directorate Student Development. Cooperation between all stakeholders will ensure the forming of a community of practice relating to the academic development of TUT students. Also, we advocate the development of more training librarians in the effective use of technology-based training of students in order to sustain the ILTP. Continued support from the LIS EXCO is necessary to further the design, maintenance and delivery of the ILTP to TUT students and academics through the allocation of adequate resources and funding.

We propose that through a process of developmental research, the following issues be investigated:

- What institutional structures are necessary to further develop and maintain an ILTP for a new generation TUT students?

- How can a new ILTP be developed to become part of a credit-bearing programme linked to life-long learning development of TUT students?

- What would the return of investment (RIO) be for a fully-developed ILTP in terms of infrastructure, human resources, development costs, and gains in terms of student development?

\section{References}

BUNDY, A. (Ed.) (2004) Australian and New Zealand Information Literacy Framework principles, standards and practice, Adelaide, Australian and New Zealand Institute for Information Literacy.

COGNITIVE APTITUDE ASSESSMENT (2004) Baseline Evaluation.

DE JAGER, K. \& SAYED, Y. (1998) Aspects of information literacy at five institutions of higher education in the Western Cape. South African journal of higher education, 12, 197-203.

GUTIERREZ, C. \& WANG, J. (200I) A comparison of an electronic vs. print workbook for information literacy instruction. The Journal of Academic Librarianship, 27, 208-2I2.

HELLER-ROSS, H. (1999) Library support for distance learning programs: A distributed model The Journal of Library Services for Distance Education

LIPPENCOTT, J. K. (2005) Net generation students \& libraries. Educause, March/April 2005, 56-66.

MACHET, M. P. (2005) An evaluation of information literacy courses offered at a distance education university. Mousaion, 23, 180-195.

MACHET, M. P. \& BEHRENS, S. (2000) Information literacy through distance learning. Innovation, 8-14.

MAYBEE, C. (2006) Undergraduate perceptions of information use: the basis for creating user-centered student information literacy instruction. The Journal of Academic Librarianship, 32, 79-85.

OJEDOKUN, A. A. (2000) Library support services for distance education in Southern Africa. Africa Journal of Library, Archives and Information Studies.

QUINLAN, N. \& HEGARTY, N. (2006) Librarians outside the box: Waterford Institute of Technology's library-based virtual learning environment (VLE) training and development programme. New Library World, 107, 37-47.

SCOTT, G. \& ALEXANDER, S. (2000) Online learning: rhetoric or reality?

SOUTH AFRICAN QUALIFICATIONS AUTHORITY (2000) The National Qualifications Framework and the Standards Setting. Pretoria.

TAPSCOTT, D. (1998) Growing up digital: the rise of the Net Generation., New York, McGraw-Hill.

THÓRSTEINSDÓTTIR, G. (200I) Information-seeking behaviour of distance learning students. Information Research.

TRICARICO, M. A., THOLL, S. V. D. \& O'MALLEY, E. (200I) Managing technology: interactive online instruction for library research: the small academic library experience. The Journal of Academic Librarianship, 27, 220-223.

TUCKER, B. \& PALMER, S. (2003) Integration of information literacy training into engineering and technology education.

TUT LIBRARY AND INFORMATION SERVICES (2005a) Minutes of the Ist meeting of the Executive Committe of the library and Information Services (LIS) held on 4 February 2005 Tshwane University of Technology.

TUT LIBRARY AND INFORMATION SERVICES (2005b) Minutes of the meeting of the Library and Information Services management committee held on 14 January 2005. Tshwane University of Technology.

TUT LIBRARY AND INFORMATION SERVICES (2005c) Policy on Information Literacy Training. Tshwane University of Technology.

ZINN, S. (2000) Information Literacy in South Africa: making strides with information and communication technology. IASL Newsletter. 